\title{
The Role of Compounds Derived from Natural Supplement as Anticancer Agents in Renal Cell Carcinoma: A Review
}

\author{
Inamul Haque ${ }^{1,2,3, *}$, Arvind Subramanian ${ }^{1,+}{ }^{,}$Chao H. Huang ${ }^{2,4}$, Andrew K. Godwin ${ }^{1,5}$, \\ Peter J. Van Veldhuizen ${ }^{4}$, Snigdha Banerjee ${ }^{1,3}$ and Sushanta K. Banerjee ${ }^{1,3,6, *}$ \\ 1 Department of Pathology and Laboratory Medicine, University of Kansas Medical Center, \\ Kansas City, KS 66160, USA; arvind.subramanian@hotmail.com (A.S.); agodwin@kumc.edu (A.K.G.); \\ sbanerjee@kumc.edu (S.B.) \\ 2 Medical Oncology, Department of Internal Medicine, University of Kansas Medical Center, \\ Kansas City, KS 66160, USA; chao.huang@va.gov \\ 3 Cancer Research Unit, Kansas City Veterans Affairs Medical Center, Kansas City, MO 64128, USA \\ 4 Division of Clinical Oncology, Kansas City Veterans Affairs Medical Center, Kansas City, MO 64128, USA; \\ peter.vanveldhuizen@va.gov \\ 5 University of Kansas Cancer Center, Kansas City, KS 66160, USA \\ 6 Department of Anatomy and Cell Biology, University of Kansas Medical Center, Kansas City, KS 66160, USA \\ * Correspondence: ihaque@kumc.edu (I.H.); sbanerjee2@kumc.edu (S.K.B.); \\ Tel.: +1-913-588-4184 (I.H.); +1-816-861-4700 (ext. 57057) (S.K.B.); \\ Fax: +1-913-945-6327 (I.H.); +1-816-922-3320 (S.K.B.) \\ + Summer high school student.
}

Received: 21 November 2017; Accepted: 28 December 2017; Published: 31 December 2017

\begin{abstract}
Renal Cell Carcinoma (RCC) is the most prominent kidney cancer derived from renal tubules and accounts for roughly $85 \%$ of all malignant kidney cancer. Every year, over 60,000 new cases are registered, and about 14,000 people die from RCC. The incidence of this has been increasing significantly in the U.S. and other countries. An increased understanding of molecular biology and the genomics of RCC has uncovered several signaling pathways involved in the progression of this cancer. Significant advances in the treatment of RCC have been reported from agents approved by the Food and Drug Administration (FDA) that target these pathways. These agents have become drugs of choice because they demonstrate clinical benefit and increased survival in patients with metastatic disease. However, the patients eventually relapse and develop resistance to these drugs. To improve outcomes and seek approaches for producing long-term durable remission, the search for more effective therapies and preventative strategies are warranted. Treatment of RCC using natural products is one of these strategies to reduce the incidence. However, recent studies have focused on these chemoprevention agents as anti-cancer therapies given they can inhibit tumor cell grow and lack the severe side effects common to synthetic compounds. This review elaborates on the current understanding of natural products and their mechanisms of action as anti-cancer agents. The present review will provide information for possible use of these products alone or in combination with chemotherapy for the prevention and treatment of RCC.
\end{abstract}

Keywords: renal cell carcinoma; natural products; Epigallocatechin-3-gallate (EGCG); Englerin A; Quercetin; miRNA

\section{Introduction}

Renal Cell Carcinoma (RCC) is a disease found in the lining of the kidney tubules [1]. It is the most prominent kidney cancer in adults, accounts for roughly $85 \%$ of all malignant kidney cancer, and can 
result in a number of symptoms, including weight loss, fever, hypertension, hypercalcemia, night sweats, and malaise [2,3]. Although RCC is quite rare, it is still among the top ten cancers, often affecting people over 45 years old [4]. More specifically, this cancer affects men more than women, with the average age of diagnosis being around 60 years $[5,6]$. Its incidence rates have been gradually increasing by $2-4 \%$ every year over the past few decades [7]. The most current cancer data estimate that nearly 64,000 new cases of renal cancer will be diagnosed in the United States, while about 14,400 people will die from complications associated with renal cancer in 2017 [8]. The five-year survival rate for the patients with this disease is approximately $85 \%$ if detected and treated early, while it is only $10 \%$ when it is detected at later stages [9]. An increased understanding of molecular biology and genomics of RCC have identified several signaling pathways involved in the progress of this disease [10]. Significant advances in the treatment of RCC have been derived from agents approved by the FDA that target several pathways. These include inhibitors of mammalian target of rapamycin (mTOR) (e.g., everolimus and temsirolimus) and the tyrosine kinase inhibitors (TKIs) (e.g., sorafenib, sunitinib, pazopanib and axitinib). Everolimus and temsirolimus block the activation of AKT, hypoxia inducible factor $\alpha(\mathrm{HIF} \alpha)$ and p70S6 kinase by targeting mTOR complex 1 and 2 (mTORC1 and mTORC2), and in turn inhibit cell growth and survival. Sorafenib, sunitinib, pazopanib and axitinib target multiple pro-angiogenic growth factors such as vascular endothelial growth factor (VEGF) and platelet derived growth factor (PDGF), and their receptors VEGFR and PDGFR. These agents were approved by the FDA because they demonstrate clinical activity and increased survival in patients with metastatic disease [11-13]. These drugs showed clinical benefit without adversely impacting overall quality of life and had a positive impact on specific symptoms, e.g., cough, fevers, shortness of breath, ability to enjoy life, and worry that the condition will get worse in patients with advanced RCC. However, patients eventually relapse and develop resistance to these drugs $[12,14,15]$. To reduce the death associated with RCC, it would be important to improve methods for detection, prevention, and treatment. In this review, we will evaluate natural products traditionally studied in chemoprevention, i.e., the use of chemicals, bioactive plant compounds or dietary components to block, inhibit or reverse the development of cancer in normal or preneoplastic tissue, as therapies for the treatment of RCC.

Previous studies have found that many compounds originated from natural products could be used as both preventive and therapeutic agents. In combination with chemotherapy or alone, they have been shown to enhance the efficacy and tolerance of the chemotherapeutic agents in various cancers [16-22]. This review article will elaborate on our current understanding of the effectiveness of naturally occurring anti-cancer agents in the treatment of RCC. We summarize studies on the effects of Epigallocatechin-3-gallate (EGCG), Englerin A, Quercetin, coumarins, curcumin, and other natural products against RCC. The structures of these natural products are shown in Figure 1. 


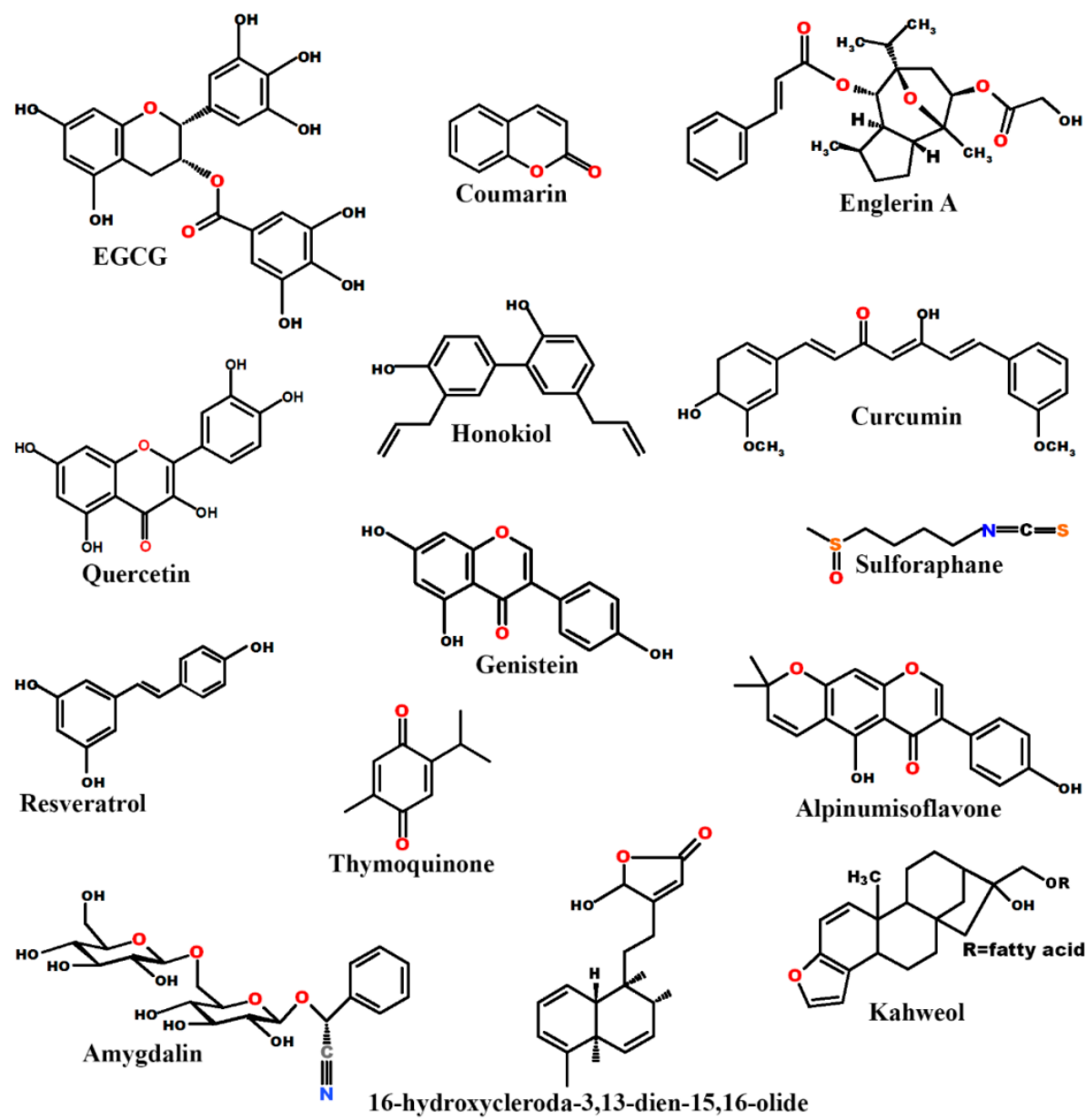

Figure 1. Chemical structures of some commonly studied natural products.

\section{Natural Products and Renal Cell Carcinoma}

Natural products have been used for thousands of years for their medicinal properties [23], yet researchers have only recently started investigating the role they play at a molecular level. These natural products are significant because their use in ancient history can be validated and applied to modern therapy with evidenced conclusions. Indeed, nearly every major ancient civilization has used some form of natural products as traditional medicines, remedies, potions and oils with many of these bioactive natural products still being unidentified [24]. The earliest records of the use of natural products for medicinal purposes can be traced to 2600 B.C., when documented oils from Cupressus sempervirens (cypress) and Commiphora species (myrrh) were used to treat illnesses [25].

Recent medical history has placed natural products on the back-burner, nearly always preferring human-made drugs derived from the study of molecular biology and combinatorial chemistry [26]. However, these drugs can often be extremely expensive [27]. Furthermore, they usually have intolerable side effects that make them prohibitive to treat human diseases, including having the opposite of the intended effect [23]. In general, herbal or natural treatments have few to no side effects while producing very favorable results in tumor treatment [23]. However, the therapeutic activities of the compounds within these products have not been studied extensively in RCC. It is thus prudent to investigate the pathways affected by compounds in these natural products.

\subsection{Epigallocatechin-3-Gallate}

A significant distinction between normal healthy cells and tumor cells is that the latter often circumvent the apoptosis process, allowing uncontrolled proliferation. Thus, inducing apoptosis 
would be an effective means of treatment. In RCC, the expression of tissue factor pathway inhibitor-2 (TFPI-2) is inversely related to the aggressiveness of these cells [28]. Therefore, higher concentrations of TFPI-2 would decrease the malignancy of these cells and most likely induce apoptosis. Epigallocatechin-3-gallate (EGCG), an active and major constituent of green tea (Camellia sinensis), displays anti-tumor properties in several cancers, including RCC [29-35] and inhibits tumor growth and invasiveness in RCC by upregulating expression of TFPI-2 through inhibition of DNA methyltransferase (DNMT) activity [28].

A recent paper indicates that EGCG may play a preventive role in the development of RCC [36]. This study evaluated the effect of tumor necrosis factor-related apoptosis-inducing ligand (TRAIL), EGCG, and a combination of both on a TRAIL-resistant RCC cell line, 786-O. The data demonstrate that EGCG alone provided a significant reduction in cell viability, but co-treatment with TRAIL provided a marked reduction in cell viability greater than that of EGCG or TRAIL alone by downregulating c-FLIP, MCl-1, and BCl-2.

Another study reported that EGCG induces apoptosis, inhibiting the proliferation and migratory potential of RCC cell lines by downregulating the expression of matrix metalloproteinase-2 (MMP-2) and matrix metalloproteinase-9 (MMP-9) [37]. However, this study did not determine how the expression levels and activity of these metalloproteinases are regulated by EGCG.

It is clear through multiple, independent experiments that EGCG has proven an extremely viable treatment in vitro. A few methods to utilize EGCG arise from the data previously presented. One example was an extensive epidemiological study which reported an inverse correlation between green tea consumption and overall RCC tumor burden [38]. Another approach might use EGCG in supplement with TKI or mTOR inhibitors to see if the combination particularly sensitizes the tumor cells as compared to TKI or mTOR inhibitor alone [39-42]. A study by Sato et al., suggests that the restoration of connexin 32 ( $C \times 32)$ gene, a tumor suppressor, by EGCG pretreatment enhanced the chemical sensitivity of vinblastine via the inactivation of Src and the activation of the c-Jun NH2-terminal kinase (JNK) in RCC cells [43]. Overall, these studies suggest that EGCG could be used as both a preventative and therapeutic approach for renal cell carcinoma.

\subsection{Englerin $A$}

Englerin A is a natural product derived from the root and stem bark of Phyllanthus engleri, an indigenous African plant. It was identified to preferentially inhibit the cell growth and viability of RCC through a drug screen of the NCI 60 (National Cancer Institute 60) cell line panel [44]. This natural product is a guaiane sesquiterpene with a tricyclic structure that has a standardized procedure for synthesis in a laboratory [45].

There are multiple proposed mechanisms for the RCC growth inhibition by Englerin A which have been summarized in detail in a comprehensive review by Beutler and coworkers [46]. One such proposal comes from Ramos's group, which suggests that growth of RCC cell lines can be inhibited by Englerin A through necrotic cell death rather than apoptosis [47]. The authors report that apoptotic bodies, typical in apoptotic cell death, were not present after Englerin A treatment. Calcium ions have been associated with necrotic cell death [48]. Ramos's group tested calcium ion content in various renal cell carcinoma cell lines and found that SF-295 cells showed little relative change in ion content while A-498 cells showed a four-fold increase in concentration [47]. Although this study indicates that apoptotic bodies were not present, Williams et al., suggest otherwise [49]. Not only necrosis was observed, but apoptosis and autophagy were also noticed after $24 \mathrm{~h}$ of treatment in A498 cells [49]. In addition, their results also suggest that Englerin A-induced inhibition of RCC growth was due to cell cycle arrest by blocking G2/M transition and suppression of AKT and ERK activity.

Englerin A triggers the activity of the enzyme protein kinase $\mathrm{C} \theta(\mathrm{PKC} \theta)$, which has been shown in vitro to phosphorylate and activate heat shock factor 1 (HSF1), resulting in insulin resistance and glucose deprivation of 786-O cells [50]. However, PKC $\theta$ is not expressed in A498 cells which are the most sensitive to Englerin A [51]. This finding led researchers to investigate other possible targets. 
Reports from two independent groups suggested that the transient receptor potential cation channel, subfamily C, member 4/5 (TRPC4/5) are characteristic to Englerin A sensitivity, and thus indicate these may be targets of Englerin A [51,52]. The authors claim that Englerin A induces cell death by the elevated $\mathrm{Ca}^{2+}$ influx and membrane depolarization, which occurred much more frequently in cells that expressed high levels of TRPC4 on their surface [52]. However, a recent finding contradicts these results and suggests that Enlerin A cytotoxicity is mediated by the influx of $\mathrm{Na}^{+}$through TRPC4/TRPC1 channels [53].

A hallmark of metastasis in malignancies including renal cancer is the epithelial-mesenchymal transition (EMT), followed by invasion [54,55]. In our group, we sought to examine the effects of Englerin A in preventing the migration and invasion of RCC cell lines as well as to investigate whether Englerin A may inhibit the molecular changes associated with EMT induced by transforming growth factor- $\beta 1$ (TGF- $\beta 1$ ) [56]. We also aimed to see whether Englerin A suppresses cancer stem cell markers and spheroid formation. Our results show that Englerin A inhibits molecular changes associated with TGF- $\beta 1$-induced EMT by upregulating the epithelial markers and downregulating the mesenchymal/stem cell markers [56]. We also found that Englerin A inhibits TGF- $\beta 1$-induced angiogenesis. This study indicated that Englerin A might serve as a potential candidate for the treatment of renal cancer metastasis.

In a recent study, Batova and colleagues proposed a different mechanism for RCC cell death by Englerin A [57]. They demonstrated that Englerin A alters lipid metabolism, induces (endoplasmic reticulum) ER stress, and in turn generates an excess of ceramides, which are lethal to RCC cells. Furthermore, Englerin A induces an acute inflammatory response.

Little work has been conducted regarding in vivo models, and those that have been conducted on mouse models indicate that the levels of Englerin A required for anti-tumor activity may be lethal $[52,58]$. If the results of this in vivo model accurately reflect the natural product's effects, this would be a major impediment for its use in cancer treatment. However, the compound itself is certainly worth investigating. It would be extremely effective in treatment if a non-lethal derivative of Englerin A was found and implemented. Further, there is still an ongoing debate as to which mechanisms Englerin A uses to elicit anti-tumor effects. If it is found that Englerin A uses many pathways for tumor suppression, its use could be used extended to treat other tumors that use these pathways.

\subsection{Quercetin}

Quercetin $\left(3,3^{\prime}, 4^{\prime}, 5,7\right.$-pentahydroxyflavone) is part of a class of pigments called flavonoids that is found in many food items, such as tea, onions, grapes, and apples [59]. Quercetin itself has been shown to exhibit a chemopreventive role in several cancers including liver, lung, prostate cancers, breast and renal cancer [60-65]. This natural product has proven very effective when used in combination with other compounds [66,67]. Quercetin has a therapeutic effect when used with hyperoside in 786-0 renal cancer cells [66]. The mechanism for this activity involves downregulation of miRNA-27a, a mechanism that we have not yet explored in this article. Most natural products we have considered trigger apoptosis or necrosis using other pathways. Meanwhile, the reduction in miRNA-27a combined with an increase in ZBTB10 (the zinc finger and BTB domain-containing protein 10) triggers a decrease in specificity protein (SP) transcription factors [66]. These transcription factors are highly expressed in cancer cells, and their reduction shows the therapeutic potential of quercetin.

Methylation by catechol-O-methyltransferase (COMT) enzyme significantly decreased the chemopreventive activity of EGCG in several cancers [68-70]. Quercetin has been reported to increase the activity of EGCG in terms of bioavailability in animal models by inhibiting COMT activity [65].

Snail is a zinc-finger transcription factor and plays a key role in EMT, migration and metastasis [71,72]. Its silencing by short hairpin RNA (shRNA) inhibits cellular proliferation, cell cycle progression, cancer cell migration and promoted apoptosis in Caki-2 cell lines [67]. Quercetin together with snail silencing 
provides even strong suppressive effects toward these cells. Quercetin has significant therapeutic potential that can be honed through research and more thorough investigation.

Isoquercetin, which is hydrolyzed in vivo to quercetin is currently being assessed in combination with sunitinib (clinicaltrials.gov: NCT02446795). In this ongoing clinical trial, the investigators hypothesized that isoquercetin is able to reduce sunitinib-induced fatigue which is being reported in $51-63 \%$ of advanced RCC patients.

\subsection{Coumarin}

Coumarin (1,2-benzopyrone) belongs to a benzopyrone family of compounds found in different parts of plants, having the highest concentration in fruits, followed by roots, seeds, and leaves. It can also be synthesized in the laboratory $[73,74]$. Researchers continue to show a strong interest in coumarin and its derivatives because of their diverse pharmacological and biological properties such as anti-thrombic, scavenging of reactive oxygen species, anti-mutagenic, anti-bacterial, cycloxygenase inhibition as well as an anti-tumorigenic effect [75].

Multiple studies have demonstrated that coumarins possess cytostatic and cytotoxic properties, inhibiting growth in several human cancer cell lines in vitro. In some clinical trials, they have shown anti-proliferative activities against several cancers including RCC [74,76-81]. Keeping in mind the anti-neoplastic action of coumarins [82], Myers et al., found that coumarin in vitro inhibited the proliferation of RCC cells [83]. Coumarins isolated from Calophyllum dispar has been used as traditional medicine to treat RCC [84]. Reduction in metastatic development among patients with RCC was noted when coumarin was given orally [82]. A derivative consisting of 1,2,4-triazolin-3-one attached to 4-methylcoumarin was found to have encouraging activity against RCC cell line [85]. A recent derivative, coufin, a novel indolylcoumarin, showed potent anticancer activity both in 2D (monolayer culture) and 3D (tumor spheroid culture) by inhibiting microtubule formation and blocking the cell cycle at G2/M [86].

Since coumarin has low toxicity, there is a scientific rationale for using coumarin with other compounds in an attempt to increase their efficacies [87]. A pilot study by Marshall et al., reported a beneficial effect of coumarin and cimetidine in RCC patients [77]. In a clinical study, patients with metastatic RCC were given interferon- $\alpha$ (IFN- $\alpha$ ) plus coumarin and cimetidine, or IFN- $\alpha$-monotherapy [88]. This study claims that using coumarin plus cimetidine to IFN- $\alpha$ did not increase response rates or survival of the patients. Further studies need to be performed to resolve the potential therapeutic value of coumarins in combination with other agents.

\subsection{Curcumin}

Curcumin (1,7-bis(4-hydroxy-3-methoxyphenyl)-1E,6E-heptadiene-3,5-dione or diferuloyl methane), a natural polyphenolic phytochemical isolated from dried rhizomes of turmeric plant (Curcuma longa) has been used for centuries as traditional Indian and Chinese medicine for the treatment of a variety of diseases [89-91]. Across a variety of studies, curcumin has shown numerous pharmacological activities, including anti-inflammatory [92-94], antiviral [95,96], anti-oxidant [94], wound healing [97], hepatoprotective [98], and anti-microbial effects [99,100]. Moreover, curcumin has been used as a chemopreventive agent and an anti-cancer therapy in several human carcinomas, including colorectal [101], melanoma [102], lymphoma [103], breast [104,105], thyroid [106], head and neck [107], prostate [108], pancreatic [109,110], ovarian [111] and RCC [91,112-118].

Curcumin has been reported to efficiently induce apoptosis in vitro in various human cancer cell lines [18,119-121]. The mechanism(s) by which curcumin can induce apoptosis in RCC cells to remain poorly understood. Initial reports by Kim et al., suggest that curcumin induces apoptosis in Caki cells by activating caspase 3 and releasing mitochondrial cytochrome C [122]. Woo et al., also suggested that curcumin induced apoptosis through the dephosphorylation of AKT, down-regulation of BCL-2, BCL-XL and inhibitor of apoptosis protein (IAP) proteins, activation of caspase 3 and release of cytochrome C [114]. Zhang and groups demonstrated that curcumin significantly inhibits proliferation 
of RRC-949 cell lines and induces cell apoptosis, possibly via regulation of BCL-2 and BAX, and initiates cell cycle arrest in G2/M phase [116]. Curcumin exposure induces apoptosis through cell cycle arrest in G1-phase and increases the volume of human kidney cells by modulating chloride ion channel [91].

Moreover, curcumin has been proven to increase the efficacy of chemotherapeutic drugs. Since PI3K/AKT and mechanistic target of rapamycin (mTOR) signaling are hyper-activated in RCC, inhibition of these pathways is warranted for RCC treatment [123]. Although NVP-BEZ235 inhibits PI3K/AKT and mTOR pathways, it was not sufficient to induce apoptosis in RCC cell lines [113]. Curcumin significantly induces apoptosis in NVPBEZ235-treated cells through p53-dependent downregulation of MCL-1 and BCL-2 protein expression [113]. However, the exact mechanism continues remains unclear.

Yes-associated protein (YAP), the effector of the Hippo signaling pathway, is reported either as an oncogene or a tumor suppressor and plays contradictory roles in the development of cancer [124]. Reports from Bai et al., indicate that YAP functions as a tumor suppressor that enhances chemosensitivity via apoptosis by modulating p53 during chemotherapy [124]. Short hairpin RNA-mediated knockdown of YAP significantly inhibited cell proliferation, migration, and colony formation efficiency of RCC cells in soft agar and led to significantly reduced tumor growth in mice by activating p53 signaling and inhibiting mitogen-activated protein kinase (MAPK) signaling [125]. However, $\mathrm{Xu}$ et al., reported that combined treatment with curcumin and temsirolimus in Caki-1 and OS-RC-2 RCC cell lines markedly upregulates YAP, which binds to p53 promoter, enhances p53 expression and finally induces apoptosis by activation of cleaved poly ADP-ribose polymerase (PARP) and caspase 3, and downregulation of BCL-2 protein expression [115]. Curcumin sensitizes human renal cancer cells to tumor necrosis factor-related apoptosis-inducing ligand (TRAIL)-induced apoptosis by upregulating death receptor 5 (DR5) expression and generating reactive oxygen species (ROS) [126]. The results from these studies suggest that using curcumin is a potentially novel and efficient strategy to enhance the effectiveness of targeted drugs in human RCC.

Although curcumin has been successfully proven to be very effective in vitro in diminishing cancer cell proliferation, migration, and invasion, it exhibits lesser effects in vivo due to poor bioavailability, poor absorption, rapid metabolism in liver cells and intestinal wall. Several strategies such as novel drug delivery systems, blocking of metabolic pathways, and synthesis of curcumin analogs have been explored in attempting to improve the bioavailability and gain in its metabolic stability [112,127-132]. We anticipate that use of curcumin or its analogs in clinics for the prevention and/or treatment of RCC and other cancers.

\subsection{Resveratrol}

Resveratrol (trans 3,4',5-trihydroxystilbene) is a naturally occurring polyphenolic compound found in grapes and 72 additional plant species and is relatively abundant in red wines [133]. It has been reported to induce apoptosis, inhibit tumor growth, and suppress angiogenesis and metastasis in various malignancies including RCC [134]. The results from microarray gene expression profiling revealed that resveratrol modulates the genes related to the inhibition of cell growth and induction of apoptosis [133]. It has been indicated that resveratrol significantly inhibits the RRC cell proliferation and exerts an antitumor effect by concomitant inhibition of the expression of VEGF, a vital feature of RCC microenvironment [135]. In a recent study, Kim et al. [134] demonstrated the pro-apoptotic and anti-invasive role of resveratrol in RCC, and their results suggest that it suppresses the activation of signal transducers and activators of transcription 3/5 (STAT3/5) proteins, which are aberrantly activated in RCC [136]. Furthermore, resveratrol induced S-phase arrest and apoptosis, decreased mitochondrial membrane potential, and suppressed colony formation in RCC. They also found that resveratrol shows caspase 3-mediated apoptosis, and blockage of metastasis by downregulating the expression of BCL-2, BCL-XL, IAP1/2, survivin, COX-2, MMP2 and VEGF.

Besides, resveratrol increases sorafenib induced inhibitory effect on phosphorylation of STAT3/5, apoptosis, and in turn results in downregulation of various oncogenic gene products. In addition to its 
antitumor action, resveratrol can exhibit antitumor immune response. It boosts antitumor immunity in mice by efficiently suppressing regulatory T cells (Tregs), inhibiting TGF- $\beta$ level, and increasing IFN- $\gamma$ expressing $\mathrm{CD}^{+} \mathrm{T}$ cells [137]. In agreement to these results, Chen et al., reported that resveratrol reduces Tregs cells, stimulates cytotoxic $\mathrm{CD} 8^{+} \mathrm{T}$ cells, increases IFN- $\gamma$ and reducing the level of interleukin-6 (IL-6) and IL-10 [138]. Moreover, they also revealed that resveratrol suppresses tumor growth by significantly inhibiting abnormal angiogenesis by downregulating VEGF level. Taken together, resveratrol may, therefore, be an effective antitumor therapy drug and improve outcomes for RCC patients.

\subsection{Other Natural Products}

There are additional natural bioactive products which possess anticancer activities against RCC. Honokiol (( $3^{\prime}, 5$-di-(2-propenyl)-1,1'-biphenyl-2,2'-diol) is a biologically active biphenolic compound isolated from Magnolia spp. bark, which has been extensively used in traditional Chinese medicine and shown to exhibit an anticancer effect in various cancer [139-144]. However, very limited literature is available which deciphers the anticancer role of honokiol in RCC. Honokiol suppresses cell proliferation and migration of highly metastatic RCC cell line, 786-0 through activation of RhoA/ROCK/MLC signaling [145]. Li et al., demonstrated that honokiol inhibits metastasis through reversing EMT and suppressing cancer stem cell (CSC) properties via modulating miR-141/ZEB2 axis [146]. Another group also shows that honokiol suppresses the invasion and metastasis by upregulating the expression of metastasis suppressor genes like KISS-1, TIMP4, KISS-1R and TP53, and concomitant downregulating CXCL12, CCL7, IL-18, and MMP7 expression in RCC cells [145]. These studies suggest that honokiol may be a suitable therapeutic approach for RCC treatment.

Genistein (4',5,7-trihydroxyflavone or 5,7-dihydroxy-3-(4-hydroxyphenyl)-4H-chromen-4-one) is one of the principal isoflavones found in soybeans. Many studies have shown that genistein inhibits several cancers by modulating different signaling pathways involved in cell cycle progression, apoptosis, invasion, angiogenesis and metastasis [147-150]. Genistein inhibits angiogenesis in vivo by downregulating the expression of VEGF and basic fibroblast growth factor (bFGF), the two crucial players in angiogenesis in RCC [151,152]. Sasamura et al., reported that genistein displays anti-proliferative action on RCC cell lines by inducing apoptosis [152]. Whereas, Majid et al., revealed that anti-proliferative action of genistein is due to cell cycle arrest at G2/M phase but not due to apoptosis [153]. They have reported for the first time that a tumor suppressor gene, BTG3 (B-cell translocation gene 3) is epigenetically silenced in RCC and genistein can reactivate it by promoter demethylation and active histone modification [153]. miR-1260b, which is an oncogenic miRNA, is overexpressed in RCC which promotes cell proliferation and invasion, and inhibits several tumor suppressor genes associated with Wnt-signaling-induced tumorigenesis, such as $s F R P 1, D k k 2$ and Smad4 [154]. Genistein downregulates miR-1260 expression and in turn, inhibits cell proliferation and invasion [154]. These studies support that genistein can be considered a promising agent for the treatment of RCC.

Sulforaphane (SFN) is an isothiocyanate derived from cruciferous vegetables such as broccoli (Brassica oleracea). SFN has been shown to play a bidirectional role; it acts as a protectant in normal kidney tubular cells against nephrotoxicants secreted by these cells, whereas it exhibits a pro-apoptotic effect on cancer cells by stimulating mitochondrial metabolism [155]. Moreover, studies found that SFN delays the resistance caused by chronic use of everolimus monotherapy and increases the efficacy of everolimus in RCC cell lines [156,157]. Further studies are warranted to verify these results in animal models.

Amygdalin (D-mandelonitrile- $\beta$-D-glucoside-6- $\beta$-glucoside), a cyanogenic substance is found in apricots, peaches, apple, cherry, plums, and other rosaceous fruit seeds [158]. Although a number of studies reported its anti-cancer properties in various cancers such as triple negative breast cancer, non-small lung cancer, prostate cancer, cervical cancer and liver cancer [158-161], very limited studies have been carried out to uncover its mechanism of action in RCC. Recently, it has been 
reported that amygdalin inhibits the growth of RCC cells by blocking adhesion and migration via an integrin-dependent mechanism $[162,163]$.

Thymoquinone (2-methyl-5-isopropyl-1,4-benzoquinone), a monoterpene, is a natural polyphenolic compound found abundantly in the seed oil of black cumin (Nigella sativa L.) seeds and known to have anti-cancer properties [164]. Thymoquinone has recently been reported for its role in inducing apoptosis through downregulation of c-FLIP and BCL-2 in renal carcinoma cells [165]. Kahweol, a diterpene molecule from coffee beans has been reported to enhance the sensitivity to sorafenib in renal cell carcinoma cells through downregulation of MCL-1 and c-FLIP expression [166].

Alpinumisoflavone is isolated from Erythrina lysistemon and little is known about its anti-cancer effect in RCC. Recently, Wang et al., uncovered the mechanism of its anti-cancer effect suggested that this natural compound suppresses the tumor growth and metastasis through modulating miR-101/RLIP76 signaling [167].

16-hydroxycleroda-3,13-dien-15,16-olide, a clerodane diterpene (CD) isolated from Polyalthia longifolia var. pendula leaves has shown has been shown to inhibit the proliferation of various human cancer cell lines [168]. However, the mechanism of action of CD against RCC remains unknown. A recent study elucidated the mechanism of action of $C D$ against RCC and suggested that it inhibits the cell proliferation and induces mitochondrial-dependent apoptosis through AKT, mTOR, and MEK/ERK pathways in RCC cells [169].

A very recent report demonstrates that Korean red ginseng extract can enhance the anticancer effect of sorafenib through suppressing cyclic adenosine monophosphate response element-binding protein and c-Jun activation, induce p53 phosphorylation and in turn enhances the chemosensitivity of sorafenib in RCC [170].

\section{Conclusions}

There are currently many agents available for the treatment of RCC such as anti-angiogenesis drugs (TKIs and bevacizumab) and immunotherapy drugs (interleukin and interferon). Renal cell carcinoma is one of the deadliest cancers, and, despite these many therapeutic options, is not curable in advanced stages. There is a clear necessity for medicines that are effective against the tumor while sparing the patient of adverse drug reactions. As an alternative approach, nature products have been proposed, but, to date, few of these compounds have been implemented on a large-scale in the treatment of cancer patients. Recent studies have suggested that many natural compounds are quite effective in vitro, and in vivo cancer models and history has shown this class of agent has little to no adverse side effects. EGCG, Englerin A, curcumin, resveratrol, quercetin, and honokiol are a few of these natural compounds that have shown beneficial results in preclinical studies of RCC. We have summarized the anticancer mechanism of these compounds in Table 1. It is prudent to continue to explore natural products as anti-tumor agents, without severe side effects, either alone or in rationally designed combination.

Table 1. Anticancer Indications of Natural Products in Renal Cell Carcinoma.

\begin{tabular}{cccc}
\hline Natural Products & Sources & Possible Targets & References \\
\hline EGCG & $\begin{array}{c}\text { Green tea, plums, apple } \\
\text { peel, onions }\end{array}$ & $\begin{array}{c}\text { TFPI-2, TRAIL, c-FLIP, MCL-1, BCL-2, } \\
\text { MMP-2/9, Cx32, Src, JNK signaling }\end{array}$ & {$[28,36,37,43]$} \\
\hline Englerin A & Phyllanthus engleri & $\begin{array}{c}\text { AKT/ERK signaling, pathway, PKC }, \\
\text { HSF1, TRPC4/5, E-cadherins, Vimentin, } \\
\text { CD44, ALDH1A1 }\end{array}$ & {$[44,47-52,56]$} \\
\hline Quercetin & $\begin{array}{c}\text { Tea, onions, grapes, } \\
\text { and apples }\end{array}$ & miRNA-27a, COMT, ZBTB10, Snail & {$[65,66]$} \\
\hline Coumarin & $\begin{array}{c}\text { Strawberry, sweet grass, } \\
\text { Tonka beans, Lavender }\end{array}$ & Caspase-9, G2/M phase & {$[82-84,86]$} \\
\hline
\end{tabular}


Table 1. Cont.

\begin{tabular}{|c|c|c|c|}
\hline Natural Products & Sources & Possible Targets & References \\
\hline Curcumin & $\begin{array}{l}\text { Rhizomes of } \\
\text { turmeric plant }\end{array}$ & $\begin{array}{l}\text { BCL-2, BCL-XL, IAP, caspase 3, } \\
\text { cytochrome c, PARP, DR5, PI3K/AKT } \\
\text { and mTOR signaling pathways }\end{array}$ & {$[91,113-116,122,123,125,126]$} \\
\hline Resveratrol & Grapes, red wines & $\begin{array}{l}\text { VEGF, STAT3/5, BCL-2, BCL-XL, } \\
\text { IAP1 } / 2 \text {, survivin, COX-2, MMP2, } \\
\text { TGF- } \beta \text {, IFN- } \gamma \text {, IL-6 and IL-10 }\end{array}$ & {$[133,135-138]$} \\
\hline Honokiol & Magnolia spp. bark & $\begin{array}{c}\text { RhoA/ROCK/MLC signaling } \\
\text { pathways, miR-141, ZEB2, KISS-1, } \\
\text { TIMP4, KISS-1R, TP53, CXCL12, CCL7, } \\
\text { IL-18, and MMP7 }\end{array}$ & {$[145,146]$} \\
\hline Genistein & Soybeans & $\begin{array}{l}\text { VEGF, bFGF, BTG3, miR-1260b, sFRP1, } \\
\text { Dkk2 and Smad4 }\end{array}$ & [151-154] \\
\hline Sulforaphane & Broccoli & Nrf2, PGC1 $\alpha$, HIF1 $\alpha$ & [155] \\
\hline Amygdalin & $\begin{array}{l}\text { apricots, peaches, apple, } \\
\text { cherry, plums }\end{array}$ & integrin $\alpha$ and $\beta$, FAK & {$[162,163]$} \\
\hline Thymoquinone & Black cumin & c-FLIP and Bcl-2 & [165] \\
\hline Kahweol & Coffee beans & Mcl-1 and c-FLIP & [166] \\
\hline Alpinumisoflavone & Erythrina lysistemon & miR-101/RLIP76 signaling & [167] \\
\hline Clerodane diterpene & Polyalthia longifolia & Akt, mTOR, and MEK/ERK & [169] \\
\hline \multicolumn{4}{|c|}{$\begin{array}{l}\text { EGCG, Epigallocatechin-3-gallate; TFPI-2, tissue factor pathway inhibitor-2; TRAIL, tumor necrosis factor-related } \\
\text { apoptosis-inducing ligand; c-FLIP, FLICE-like inhibitory protein; McL-1, myeloid cell leukemia 1; Bcl-2, B-cell } \\
\text { lymphoma 2; MMP, matrix metalloproteinas; Cx32, connexin 32; JNK, Jun N-terminal protein kinase; ERK, extracellular } \\
\text { signal-regulated kinase; PKC } \theta \text {, protein kinase C theta; HSF1, heat sock factor 1; TRPC, transient receptor potential cation } \\
\text { channel; ALDH1A1, Aldehyde dehydrogenase } 1 \text { family, member A1; COMT, catechol-O-methyltransferase; ZBTB10, } \\
\text { zinc finger and BTB domain-containing protein } 10 ; \text { IAP, inhibitor of apoptosis protein; PARP, poly ADP-ribose polymerase; } \\
\text { DR5, death receptor 5; PI3K, phosphoinositide 2-kinase; mTOR, Mechanistic target of rapamycin; VEGF, vascular } \\
\text { endothelial growth factor, STAT3/5, Signal transducer and activator of transcription } 3 / 5 \text {; COX-2, cyclooxygenase-2; } \\
\text { TGF- } \beta \text {, transforming growth factor } \beta \text {; IFN- } \gamma \text {, interferon gamma; IL, interleukin; ROCK, Rho-associated coiled-coil kinase; } \\
\text { MLC, myosin light chain; KISS1, Kisspeptin; TIMP4, tissue inhibitors of metalloproteinase 4; CXCL12, Chemokine } \\
\text { (C-X-C motif) ligand 12; CCL7, Chemokine ligand 7; bFGF, basic fibroblast growth factor; BTG3, B-cell translocation } \\
\text { gene 3; sFRP1, Secreted frizzled-related protein } 1 \text {; Dkk2, Dickkopf WNT Signaling Pathway Inhibitor 2; Smad4, Smad } \\
\text { Family Member 4; Nrf2, Nuclear factor E2-related factor 2; PGC1 } \alpha \text {, proliferator-activated receptor- } \gamma \text { co-activator- } \alpha \text {; } \\
\text { HIF1 } \alpha \text {, hypoxia-inducible factor-1 } \alpha \text {; FAK, focal adhesion kinase; c-FLIP, cellular FLICE (FADD-like IL-1 } \beta \text {-converting } \\
\text { enzyme-inhibitory protein; RLIP76, Ral-interacting protein of } 76 \mathrm{kDa} \text {. }\end{array}$} \\
\hline
\end{tabular}

Acknowledgments: We greatly appreciate John Beutler (Center for Cancer Research, National Cancer Institute, Frederick, MD) for his valuable and helpful comments on this manuscript. This work was supported by Basic Research Development Award from Internal Medicine, KUMC (Inamul Haque ), the Kansas City Area Life Science grant award (Sushanta K. Banerjee), Merit review grant from Department of Veterans Affairs (Sushanta K. Banerjee, 5I01BX001989-03 and Snigdha Banerjee,1I01BX001002-04), and KUMC Van Goethem Family Endowed Funds (Sushanta K. Banerjee). Andrew K. Godwin is the Chancellors Distinguished Chair in Biomedical Sciences Endowed Professor.

Author Contributions: Inamul Haque and Arvind Subramanian performed the literature search and wrote the manuscript; Chao H. Huang and Peter J. Van Veldhuizen helped revise the draft; Andrew K. Godwin, Snigdha Banerjee and Sushanta K. Banerjee provided their expert comments and editing.

Conflicts of Interest: The authors declare no conflict of interest.

\section{References}

1. Shroff, E.H.; Eberlin, L.S.; Dang, V.M.; Gouw, A.M.; Gabay, M.; Adam, S.J.; Bellovin, D.I.; Tran, P.T.; Philbrick, W.M.; Garcia-Ocana, A.; et al. MYC oncogene overexpression drives renal cell carcinoma in a mouse model through glutamine metabolism. Proc. Natl. Acad. Sci. USA 2015, 112, 6539-6544. [CrossRef] [PubMed]

2. He, Y.H.; Chen, C.; Shi, Z. The Biological Roles and Clinical Implications of MicroRNAs in Clear Cell Renal Cell Carcinoma. J. Cell. Physiol. 2017. [CrossRef] [PubMed]

3. Sullivan, S. Paraneoplastic Cough and Renal Cell Carcinoma. Can. Respir. J. 2016, 2016, 5938536. [CrossRef] [PubMed] 
4. Malouf, G.G.; Camparo, P.; Oudard, S.; Schleiermacher, G.; Theodore, C.; Rustine, A.; Dutcher, J.; Billemont, B.; Rixe, O.; Bompas, E.; et al. Targeted agents in metastatic Xp11 translocation/TFE3 gene fusion renal cell carcinoma (RCC): A report from the Juvenile RCC Network. Ann. Oncol. 2010, 21, 1834-1838. [CrossRef] [PubMed]

5. Monteiro, M.S.; Barros, A.S.; Pinto, J.; Carvalho, M.; Pires-Luis, A.S.; Henrique, R.; Jeronimo, C.; Bastos, M.L.; Gil, A.M.; Guedes de Pinho, P. Nuclear Magnetic Resonance metabolomics reveals an excretory metabolic signature of renal cell carcinoma. Sci. Rep. 2016, 6, 37275. [CrossRef] [PubMed]

6. Qu, Y.; Chen, H.; Gu, W.; Gu, C.; Zhang, H.; Xu, J.; Zhu, Y.; Ye, D. Age-dependent association between sex and renal cell carcinoma mortality: A population-based analysis. Sci. Rep. 2015, 5, 9160. [CrossRef] [PubMed]

7. Kwon, R.J.; Kim, Y.H.; Jeong, D.C.; Han, M.E.; Kim, J.Y.; Liu, L.; Jung, J.S.; Oh, S.O. Expression and prognostic significance of zinc fingers and homeoboxes family members in renal cell carcinoma. PLoS ONE 2017, 12, e0171036. [CrossRef] [PubMed]

8. Siegel, R.L.; Miller, K.D.; Jemal, A. Cancer Statistics, 2016. CA Cancer J. Clin. 2016, 66, 7-30. [CrossRef] [PubMed]

9. Motzer, R.J.; Bander, N.H.; Nanus, D.M. Renal-cell carcinoma. N. Engl. J. Med. 1996, 335, 865-875. [CrossRef] [PubMed]

10. Thakur, A.; Jain, S.K. Kidney Cancer: Current Progress in Treatment. World J. Oncol. 2011, 2, 158-165. [PubMed]

11. Heng, D.Y.; Chi, K.N.; Murray, N.; Jin, T.; Garcia, J.A.; Bukowski, R.M.; Rini, B.I.; Kollmannsberger, C. A population-based study evaluating the impact of sunitinib on overall survival in the treatment of patients with metastatic renal cell cancer. Cancer 2009, 115, 776-783. [CrossRef] [PubMed]

12. Rini, B.I. New strategies in kidney cancer: Therapeutic advances through understanding the molecular basis of response and resistance. Clin. Cancer Res. 2010, 16, 1348-1354. [CrossRef] [PubMed]

13. Varella, L.; Rini, B.I. Emerging drugs for renal cell carcinoma. Expert Opin. Emerg. Drugs 2010, 15, $343-353$. [CrossRef] [PubMed]

14. Ebos, J.M.; Lee, C.R.; Cruz-Munoz, W.; Bjarnason, G.A.; Christensen, J.G.; Kerbel, R.S. Accelerated metastasis after short-term treatment with a potent inhibitor of tumor angiogenesis. Cancer Cell 2009, 15, 232-239. [CrossRef] [PubMed]

15. Ebos, J.M.; Lee, C.R.; Kerbel, R.S. Tumor and host-mediated pathways of resistance and disease progression in response to antiangiogenic therapy. Clin Cancer Res. 2009, 15, 5020-5025. [CrossRef] [PubMed]

16. Farabegoli, F.; Papi, A.; Bartolini, G.; Ostan, R.; Orlandi, M. (-)-Epigallocatechin-3-gallate downregulates Pg-P and BCRP in a tamoxifen resistant MCF-7 cell line. Phytomedicine 2010, 17, 356-362. [CrossRef] [PubMed]

17. Nautiyal, J.; Banerjee, S.; Kanwar, S.S.; Yu, Y.; Patel, B.B.; Sarkar, F.H.; Majumdar, A.P. Curcumin enhances dasatinib-induced inhibition of growth and transformation of colon cancer cells. Int. J. Cancer 2011, 128, 951-961. [CrossRef] [PubMed]

18. Sen, S.; Sharma, H.; Singh, N. Curcumin enhances Vinorelbine mediated apoptosis in NSCLC cells by the mitochondrial pathway. Biochem. Biophys. Res. Commun. 2005, 331, 1245-1252. [CrossRef] [PubMed]

19. Wang, C.Z.; Yuan, C.S. Potential role of ginseng in the treatment of colorectal cancer. Am. J. Chin. Med. 2008, 36, 1019-1028. [CrossRef] [PubMed]

20. Banerjee, S.; Kambhampati, S.; Haque, I.; Banerjee, S.K. Pomegranate sensitizes Tamoxifen action in ER- $\alpha$ positive breast cancer cells. J. Cell Commun. Signal. 2011, 5, 317-324. [CrossRef] [PubMed]

21. Ishii, T.; Teramoto, S.; Matsuse, T. GSTP1 affects chemoresistance against camptothecin in human lung adenocarcinoma cells. Cancer Lett. 2004, 216, 89-102. [CrossRef] [PubMed]

22. Nakashima, K.; Virgona, N.; Miyazawa, M.; Watanabe, T.; Yano, T. The tocotrienol-rich fraction from rice bran enhances cisplatin-induced cytotoxicity in human mesothelioma H28 cells. Phytother. Res. 2010, 24, 1317-1321. [CrossRef] [PubMed]

23. Ji, H.F.; Li, X.J.; Zhang, H.Y. Natural products and drug discovery. Can thousands of years of ancient medical knowledge lead us to new and powerful drug combinations in the fight against cancer and dementia? EMBO Rep. 2009, 10, 194-200. [CrossRef] [PubMed]

24. Petrovska, B.B. Historical review of medicinal plants' usage. Pharmacogn. Rev. 2012, 6, 1-5. [CrossRef] [PubMed] 
25. Cragg, G.M.; Newman, D.J. Biodiversity: A continuing source of novel drug leads. Pure Appl. Chem. 2005, 77, 7-24. [CrossRef]

26. Czarnik, A.W.; Keene, J.D. Combinatorial chemistry. Curr. Biol. 1998, 8, R705-R707. [CrossRef]

27. Siddiqui, M.; Rajkumar, S.V. The high cost of cancer drugs and what we can do about it. Mayo Clin. Proc. 2012, 87, 935-943. [CrossRef] [PubMed]

28. Gu, B.; Ding, Q.; Xia, G.; Fang, Z. EGCG inhibits growth and induces apoptosis in renal cell carcinoma through TFPI-2 overexpression. Oncol. Rep. 2009, 21, 635-640. [PubMed]

29. Das, A.; Banerjee, S.; De, A.; Haque, I.; Maity, G.; McEwen, M.; Banerjee, S.K. The green tea polyphenol EGCG induces Mesenchymal to Epithelial Transition (MET) and tumor regression in Triple Negative Breast Cancer (TNBC) cells and mouse-xenograft model: Involvement of CCN5. Cancer Res. 2013, 73 (Suppl. S8). [CrossRef]

30. Fang, M.Z.; Wang, Y.; Ai, N.; Hou, Z.; Sun, Y.; Lu, H.; Welsh, W.; Yang, C.S. Tea polyphenol (-)-epigallocatechin-3-gallate inhibits DNA methyltransferase and reactivates methylation-silenced genes in cancer cell lines. Cancer Res. 2003, 63, 7563-7570. [PubMed]

31. Katiyar, S.; Mukhtar, H. Tea in chemoprevention of cancer. Int. J. Oncol. 1996, 8, 221-238. [CrossRef] [PubMed]

32. Khan, N.; Mukhtar, H. Cancer and metastasis: Prevention and treatment by green tea. Cancer Metastasis Rev. 2010, 29, 435-445. [CrossRef] [PubMed]

33. Suganuma, M.; Okabe, S.; Sueoka, N.; Sueoka, E.; Matsuyama, S.; Imai, K.; Nakachi, K.; Fujiki, H. Green tea and cancer chemoprevention. Mutat. Res. 1999, 428, 339-344. [CrossRef]

34. Wang, H.; Bian, S.; Yang, C.S. Green tea polyphenol EGCG suppresses lung cancer cell growth through upregulating miR-210 expression caused by stabilizing HIF-1 $\alpha$. Carcinogenesis 2011, 32, 1881-1889. [CrossRef] [PubMed]

35. Zhou, X.Q.; Xu, X.N.; Li, L.; Ma, J.J.; Zhen, E.M.; Han, C.B. Epigallocatechin-3-gallate inhibits the invasion of salivary adenoid cystic carcinoma cells by reversing the hypermethylation status of the RECK gene. Mol. Med. Rep. 2015, 12, 6031-6036. [CrossRef] [PubMed]

36. Wei, R.; Zhu, G.; Jia, N.; Yang, W. Epigallocatechin-3-gallate Sensitizes Human 786-O Renal Cell Carcinoma Cells to TRAIL-Induced Apoptosis. Cell. Biochem. Biophys. 2015, 72, 157-164. [CrossRef] [PubMed]

37. Chen, S.J.; Yao, X.D.; Peng, B.O.; Xu, Y.F.; Wang, G.C.; Huang, J.; Liu, M.; Zheng, J.H. Epigallocatechin-3-gallate inhibits migration and invasion of human renal carcinoma cells by downregulating matrix metalloproteinase-2 and matrix metalloproteinase-9. Exp. Ther. Med. 2016, 11, 1243-1248. [CrossRef] [PubMed]

38. Lee, J.E.; Hunter, D.J.; Spiegelman, D.; Adami, H.O.; Bernstein, L.; van den Brandt, P.A.; Buring, J.E.; Cho, E.; English, D.; Folsom, A.R.; et al. Intakes of coffee, tea, milk, soda and juice and renal cell cancer in a pooled analysis of 13 prospective studies. Int. J. Cancer 2007, 121, 2246-2253. [CrossRef] [PubMed]

39. Liao, H.; Xiao, Y.; Hu, Y.; Xiao, Y.; Yin, Z.; Liu, L.; Kang, X.; Chen, Y. Inhibitory effect of epigallocatechin-3-gallate on bladder cancer cells via autophagy pathway. Int. J. Clin. Exp. Med. 2016, 9, 9868-9878.

40. Fei, S.J.; Zhang, X.C.; Dong, S.; Cheng, H.; Zhang, Y.F.; Huang, L.; Zhou, H.Y.; Xie, Z.; Chen, Z.H.; Wu, Y.L. Targeting mTOR to overcome epidermal growth factor receptor tyrosine kinase inhibitor resistance in non-small cell lung cancer cells. PLoS ONE 2013, 8, e69104. [CrossRef] [PubMed]

41. Haque, A.; Rahman, M.A.; Chen, Z.G.; Saba, N.F.; Khuri, F.R.; Shin, D.M.; Ruhul Amin, A.R. Combination of erlotinib and EGCG induces apoptosis of head and neck cancers through posttranscriptional regulation of Bim and Bcl-2. Apoptosis 2015, 20, 986-995. [CrossRef] [PubMed]

42. Zhang, X.; Zhang, H.; Tighiouart, M.; Lee, J.E.; Shin, H.J.; Khuri, F.R.; Yang, C.S.; Chen, Z.; Shin, D.M. Synergistic inhibition of head and neck tumor growth by green tea (-)-epigallocatechin-3-gallate and EGFR tyrosine kinase inhibitor. Int. J. Cancer 2008, 123, 1005-1014. [CrossRef] [PubMed]

43. Sato, A.; Sekine, M.; Kobayashi, M.; Virgona, N.; Ota, M.; Yano, T. Induction of the connexin 32 gene by epigallocatechin-3-gallate potentiates vinblastine-induced cytotoxicity in human renal carcinoma cells. Chemotherapy 2013, 59, 192-199. [CrossRef] [PubMed]

44. Ratnayake, R.; Covell, D.; Ransom, T.T.; Gustafson, K.R.; Beutler, J.A.; Englerin, A. A selective inhibitor of renal cancer cell growth, from Phyllanthus engleri. Org. Lett. 2009, 11, 57-60. [CrossRef] [PubMed] 
45. Li, Z.; Nakashige, M.; Chain, W.J. A brief synthesis of (-)-englerin, A. J. Am. Chem. Soc. 2011, 133, $6553-6556$. [CrossRef] [PubMed]

46. Wu, Z.; Zhao, S.; Fash, D.M.; Li, Z.; Chain, W.J.; Beutler, J.A. Englerins: A Comprehensive Review. J. Nat. Prod. 2017, 80, 771-781. [CrossRef] [PubMed]

47. Sulzmaier, F.J.; Li, Z.; Nakashige, M.L.; Fash, D.M.; Chain, W.J.; Ramos, J.W. Englerin a selectively induces necrosis in human renal cancer cells. PLoS ONE 2012, 7, e48032. [CrossRef] [PubMed]

48. Zong, W.X.; Thompson, C.B. Necrotic death as a cell fate. Genes Dev. 2006, 20, 1-15. [CrossRef] [PubMed]

49. Williams, R.T.; Yu, A.L.; Diccianni, M.B.; Theodorakis, E.A.; Batova, A. Renal cancer-selective Englerin A induces multiple mechanisms of cell death and autophagy. J. Exp. Clin. Cancer Res. 2013, 32, 57. [CrossRef] [PubMed]

50. Sourbier, C.; Scroggins, B.T.; Ratnayake, R.; Prince, T.L.; Lee, S.; Lee, M.J.; Nagy, P.L.; Lee, Y.H.; Trepel, J.B.; Beutler, J.A.; et al. Englerin A stimulates PKC $\theta$ to inhibit insulin signaling and to simultaneously activate HSF1: Pharmacologically induced synthetic lethality. Cancer Cell 2013, 23, 228-237. [CrossRef] [PubMed]

51. Akbulut, Y.; Gaunt, H.J.; Muraki, K.; Ludlow, M.J.; Amer, M.S.; Bruns, A.; Vasudev, N.S.; Radtke, L.; Willot, M.; Hahn, S.; et al. (-)-Englerin A is a potent and selective activator of TRPC4 and TRPC5 calcium channels. Angew. Chem. Int. Ed. Engl. 2015, 54, 3787-3791. [CrossRef] [PubMed]

52. Carson, C.; Raman, P.; Tullai, J.; Xu, L.; Henault, M.; Thomas, E.; Yeola, S.; Lao, J.; McPate, M.; Verkuyl, J.M.; et al. Englerin A Agonizes the TRPC4/C5 Cation Channels to Inhibit Tumor Cell Line Proliferation. PLoS ONE 2015, 10, e0127498. [CrossRef] [PubMed]

53. Ludlow, M.J.; Gaunt, H.J.; Rubaiy, H.N.; Musialowski, K.E.; Blythe, N.M.; Vasudev, N.S.; Muraki, K.; Beech, D.J. (-)-Englerin A-evoked Cytotoxicity Is Mediated by $\mathrm{Na}^{+}$Influx and Counteracted by $\mathrm{Na}^{+} / \mathrm{K}^{+}$-ATPase. J. Biol. Chem. 2017, 292, 723-731. [CrossRef] [PubMed]

54. Son, H.; Moon, A. Epithelial-mesenchymal Transition and Cell Invasion. Toxicol. Res. 2010, 26, $245-252$. [CrossRef] [PubMed]

55. Zhou, D.; Kannappan, V.; Chen, X.; Li, J.; Leng, X.; Zhang, J.; Xuan, S. RBP2 induces stem-like cancer cells by promoting EMT and is a prognostic marker for renal cell carcinoma. Exp. Mol. Med. 2016, 48, e238. [CrossRef] [PubMed]

56. Haque, I.; Banerjee, S.; Beutler, J.A.; Banerjee, S.K. Englerin-A prevents invasive phenotypes of renal cell carcinoma by reprogramming mesenchymal to epithelial transition: A key mechanism of its anticancer properties. Cancer Res. 2015, 75. [CrossRef]

57. Batova, A.; Altomare, D.; Creek, K.E.; Naviaux, R.K.; Wang, L.; Li, K.; Green, E.; Williams, R.; Naviaux, J.C.; Diccianni, M.; et al. Englerin A induces an acute inflammatory response and reveals lipid metabolism and ER stress as targetable vulnerabilities in renal cell carcinoma. PLoS ONE 2017, 12, e0172632. [CrossRef] [PubMed]

58. Fash, D.M.; Peer, C.J.; Li, Z.; Talisman, I.J.; Hayavi, S.; Sulzmaier, F.J.; Ramos, J.W.; Sourbier, C.; Neckers, L.; Figg, W.D.; et al. Synthesis of a stable and orally bioavailable englerin analogue. Bioorg. Med. Chem. Lett. 2016, 26, 2641-2644. [CrossRef] [PubMed]

59. Kim, M.J.; Kim, Y.J.; Park, H.J.; Chung, J.H.; Leem, K.H.; Kim, H.K. Apoptotic effect of red wine polyphenols on human colon cancer SNU-C4 cells. Food Chem. Toxicol. 2006, 44, 898-902. [CrossRef] [PubMed]

60. Deng, X.H.; Song, H.Y.; Zhou, Y.F.; Yuan, G.Y.; Zheng, F.J. Effects of quercetin on the proliferation of breast cancer cells and expression of survivin in vitro. Exp. Ther. Med. 2013, 6, 1155-1158. [CrossRef] [PubMed]

61. Granado-Serrano, A.B.; Martin, M.A.; Bravo, L.; Goya, L.; Ramos, S. Quercetin modulates NF-kB and AP-1/JNK pathways to induce cell death in human hepatoma cells. Nutr. Cancer 2010, 62, 390-401. [CrossRef] [PubMed]

62. Han, C.G.H.; Zhang, W. The anti-cancer effect of Quercetin in renal cancer through regulating survivin expression and caspase 3 activity. Med. One 2016, 1, 7.

63. Hsieh, C.L.; Peng, C.C.; Cheng, Y.M.; Lin, L.Y.; Ker, Y.B.; Chang, C.H.; Chen, K.C.; Peng, R.Y. Quercetin and ferulic acid aggravate renal carcinoma in long-term diabetic victims. J. Agric. Food Chem. 2010, 58, 9273-9280. [CrossRef] [PubMed]

64. Srivastava, S.; Somasagara, R.R.; Hegde, M.; Nishana, M.; Tadi, S.K.; Srivastava, M.; Choudhary, B.; Raghavan, S.C. Quercetin, a Natural Flavonoid Interacts with DNA, Arrests Cell Cycle and Causes Tumor Regression by Activating Mitochondrial Pathway of Apoptosis. Sci. Rep. 2016, 6, 24049. [CrossRef] [PubMed] 
65. Wang, P.; Heber, D.; Henning, S.M. Quercetin increased bioavailability and decreased methylation of green tea polyphenols in vitro and in vivo. Food Funct. 2012, 3, 635-642. [CrossRef] [PubMed]

66. Li, W.; Liu, M.; Xu, Y.F.; Feng, Y.; Che, J.P.; Wang, G.C.; Zheng, J.H. Combination of quercetin and hyperoside has anticancer effects on renal cancer cells through inhibition of oncogenic microRNA-27a. Oncol. Rep. 2014, 31, 117-124. [CrossRef] [PubMed]

67. Meng, F.D.; Li, Y.; Tian, X.; Ma, P.; Sui, C.G.; Fu, L.Y.; Jiang, Y.H. Synergistic effects of snail and quercetin on renal cell carcinoma Caki-2 by altering AKT/mTOR/ERK1/2 signaling pathways. Int. J. Clin. Exp. Pathol. 2015, 8, 6157-6168. [PubMed]

68. Forester, S.C.; Lambert, J.D. Synergistic inhibition of lung cancer cell lines by (-)-epigallocatechin-3-gallate in combination with clinically used nitrocatechol inhibitors of catechol-O-methyltransferase. Carcinogenesis 2014, 35, 365-372. [CrossRef] [PubMed]

69. Henning, S.M.; Wang, P.; Carpenter, C.L.; Heber, D. Epigenetic effects of green tea polyphenols in cancer. Epigenomics 2013, 5, 729-741. [CrossRef] [PubMed]

70. Landis-Piwowar, K.; Chen, D.; Chan, T.H.; Dou, Q.P. Inhibition of catechol-Omicron-methyltransferase activity in human breast cancer cells enhances the biological effect of the green tea polyphenol (-)-EGCG. Oncol. Rep. 2010, 24, 563-569. [PubMed]

71. Wang, J.; Zhu, X.; Hu, J.; He, G.; Li, X.; Wu, P.; Ren, X.; Wang, F.; Liao, W.; Liang, L.; et al. The positive feedback between Snail and DAB2IP regulates EMT, invasion and metastasis in colorectal cancer. Oncotarget 2015, 6, 27427-27439. [CrossRef] [PubMed]

72. Wang, Y.; Shi, J.; Chai, K.; Ying, X.; Zhou, B.P. The Role of Snail in EMT and Tumorigenesis. Curr. Cancer Drug Targets 2013, 13, 963-972. [CrossRef] [PubMed]

73. Peiris, D.C. Natural Medicine as a Therapy for Renal Carcinoma: A Review. In Renal cell carcinoma, 1st ed.; SM Group: Dover, DE, USA, 2015.

74. Salem, M.A.; Marzouk, M.I.; El-Kazak, A.M. Synthesis and Characterization of Some New Coumarins with in vitro Antitumor and Antioxidant Activity and High Protective Effects against DNA Damage. Molecules 2016, 21, 249. [CrossRef] [PubMed]

75. Venkata Sairam, K.; Gurupadayya, B.M.; Chandan, R.S.; Nagesha, D.K.; Vishwanathan, B. A Review on Chemical Profile of Coumarins and their Therapeutic Role in the Treatment of Cancer. Curr. Drug Deliv. 2016, 13, 186-201. [CrossRef] [PubMed]

76. Kirkwood, J.M.; Ernstoff, M.S. Coumarin plus cimetidine: Yet another angle for therapy of renal cell carcinoma. J. Clin. Oncol. 1987, 5, 836-837. [CrossRef] [PubMed]

77. Marshall, M.E.; Mendelsohn, L.; Butler, K.; Riley, L.; Cantrell, J.; Wiseman, C.; Taylor, R.; Macdonald, J.S. Treatment of metastatic renal cell carcinoma with coumarin (1,2-benzopyrone) and cimetidine: A pilot study. J. Clin. Oncol. 1987, 5, 862-866. [CrossRef] [PubMed]

78. Marshall, M.E.; Rhoades, J.L.; Mattingly, C.; Jennings, C.D. Coumarin (1,2-benzopyrone) enhances DR and DQ antigen expressions by peripheral blood mononuclear cells in vitro. Mol. Biother. 1991, 3, $204-206$. [PubMed]

79. Mohler, J.L.; Gomella, L.G.; Crawford, E.D.; Glode, L.M.; Zippe, C.D.; Fair, W.R.; Marshall, M.E. Phase II evaluation of coumarin (1,2-benzopyrone) in metastatic prostatic carcinoma. Prostate 1992, 20, 123-131. [CrossRef] [PubMed]

80. Thakur, A.; Singla, R.; Jaitak, V. Coumarins as anticancer agents: A review on synthetic strategies, mechanism of action and SAR studies. Eur. J. Med. Chem. 2015, 101, 476-495. [CrossRef] [PubMed]

81. Finn, G.J.; Kenealy, E.; Creaven, B.S.; Egan, D.A. In vitro cytotoxic potential and mechanism of action of selected coumarins, using human renal cell lines. Cancer Lett. 2002, 183, 61-68. [CrossRef]

82. Thornes, R.D.; Lynch, G.; Sheehan, M.V. Cimetidine and coumarin therapy of melanoma. Lancet 1982, 2, 328. [CrossRef]

83. Myers, R.B.; Parker, M.; Grizzle, W.E. The effects of coumarin and suramin on the growth of malignant renal and prostatic cell lines. J. Cancer Res. Clin. Oncol. 1994, 120 (Suppl. S1), S11-S13. [CrossRef] [PubMed]

84. Guilet, D.; Seraphin, D.; Rondeau, D.; Richomme, P.; Bruneton, J. Cytotoxic coumarins from Calophyllum dispar. Phytochemistry 2001, 58, 571-575. [CrossRef]

85. Kattimani, P.P.; Kamble, R.R.; Kariduraganavar, M.Y.; Dorababu, A.; Hunnur, R.K. Synthesis, characterization and in vitro anticancer evaluation of novel 1,2,4-triazolin-3-one derivatives. Eur. J. Med. Chem. 2013, 62, 232-240. [CrossRef] [PubMed] 
86. Champelovier, P.; Barbier, P.; Daras, E.; Douillard, S.; Toussaint, B.; Persoon, V.; Combes, S. The indolylcoumarin COUFIN exhibits potent activity against renal carcinoma cells without affecting hematopoietic system. Anti-Cancer Agents Med. Chem. 2014, 14, 862-871. [CrossRef]

87. Marshall, M.E.; Butler, K.; Fried, A. Phase I evaluation of coumarin (1,2-benzopyrone) and cimetidine in patients with advanced malignancies. Mol. Biother. 1991, 3, 170-178. [PubMed]

88. Sagaster, P.; Micksche, M.; Flamm, J.; Ludwig, H. Randomised study using IFN- $\alpha$ versus IFN- $\alpha$ plus coumarin and cimetidine for treatment of advanced renal cell cancer. Ann. Oncol. 1995, 6, 999-1003. [CrossRef] [PubMed]

89. Ammon, H.P.; Wahl, M.A. Pharmacology of Curcuma longa. Planta Med. 1991, 57, 1-7. [CrossRef] [PubMed]

90. Goel, A.; Kunnumakkara, A.B.; Aggarwal, B.B. Curcumin as "Curecumin": From kitchen to clinic. Biochem. Pharmacol. 2008, 75, 787-809. [CrossRef] [PubMed]

91. Kossler, S.; Nofziger, C.; Jakab, M.; Dossena, S.; Paulmichl, M. Curcumin affects cell survival and cell volume regulation in human renal and intestinal cells. Toxicology 2012, 292, 123-135. [CrossRef] [PubMed]

92. Brouet, I.; Ohshima, H. Curcumin, an anti-tumour promoter and anti-inflammatory agent, inhibits induction of nitric oxide synthase in activated macrophages. Biochem. Biophys. Res. Commun. 1995, 206, 533-540. [CrossRef] [PubMed]

93. Jurenka, J.S. Anti-inflammatory properties of curcumin, a major constituent of Curcuma longa: A review of preclinical and clinical research. Altern. Med. Rev. 2009, 14, 141-153. [PubMed]

94. Menon, V.P.; Sudheer, A.R. Antioxidant and anti-inflammatory properties of curcumin. Adv. Exp. Med. Biol. 2007, 595, 105-125. [PubMed]

95. Chen, T.Y.; Chen, D.Y.; Wen, H.W.; Ou, J.L.; Chiou, S.S.; Chen, J.M.; Wong, M.L.; Hsu, W.L. Inhibition of enveloped viruses infectivity by curcumin. PLoS ONE 2013, 8, e62482. [CrossRef] [PubMed]

96. Rechtman, M.M.; Har-Noy, O.; Bar-Yishay, I.; Fishman, S.; Adamovich, Y.; Shaul, Y.; Halpern, Z.; Shlomai, A. Curcumin inhibits hepatitis B virus via down-regulation of the metabolic coactivator PGC- $1 \alpha$. FEBS Lett. 2010, 584, 2485-2490. [CrossRef] [PubMed]

97. Akbik, D.; Ghadiri, M.; Chrzanowski, W.; Rohanizadeh, R. Curcumin as a wound healing agent. Life Sci. 2014, 116, 1-7. [CrossRef] [PubMed]

98. Singh, R.; Sharma, P. Hepatoprotective Effect of Curcumin on Lindane-induced Oxidative Stress in Male Wistar Rats. Toxicol. Int. 2011, 18, 124-129. [PubMed]

99. De, R.; Kundu, P.; Swarnakar, S.; Ramamurthy, T.; Chowdhury, A.; Nair, G.B.; Mukhopadhyay, A.K. Antimicrobial activity of curcumin against Helicobacter pylori isolates from India and during infections in mice. Antimicrob. Agents Chemother. 2009, 53, 1592-1597. [CrossRef] [PubMed]

100. Gul, P.; Bakht, J. Antimicrobial activity of turmeric extract and its potential use in food industry. J. Food Sci. Technol. 2015, 52, 2272-2279. [CrossRef] [PubMed]

101. Park, J.; Conteas, C.N. Anti-carcinogenic properties of curcumin on colorectal cancer. World J. Gastrointest. Oncol. 2010, 2, 169-176. [CrossRef] [PubMed]

102. Mirzaei, H.; Naseri, G.; Rezaee, R.; Mohammadi, M.; Banikazemi, Z.; Mirzaei, H.R.; Salehi, H.; Peyvandi, M.; Pawelek, J.M.; Sahebkar, A. Curcumin: A new candidate for melanoma therapy? Int J. Cancer 2016, 139, 1683-1695. [CrossRef] [PubMed]

103. Das, L.; Vinayak, M. Anti-carcinogenic action of curcumin by activation of antioxidant defence system and inhibition of NF-кB signalling in lymphoma-bearing mice. Biosci. Rep. 2012, 32, 161-170. [CrossRef] [PubMed]

104. Bachmeier, B.E.; Mohrenz, I.V.; Mirisola, V.; Schleicher, E.; Romeo, F.; Hohneke, C.; Jochum, M.; Nerlich, A.G.; Pfeffer, U. Curcumin downregulates the inflammatory cytokines CXCL1 and -2 in breast cancer cells via NFkB. Carcinogenesis 2008, 29, 779-789. [CrossRef] [PubMed]

105. Liu, D.; Chen, Z. The effect of curcumin on breast cancer cells. J. Breast Cancer 2013, 16, 133-137. [CrossRef] [PubMed]

106. Xu, X.; Qin, J.; Liu, W. Curcumin inhibits the invasion of thyroid cancer cells via down-regulation of PI3K/Akt signaling pathway. Gene 2014, 546, 226-232. [CrossRef] [PubMed]

107. Hu, A.; Huang, J.J.; Li, R.L.; Lu, Z.Y.; Duan, J.L.; Xu, W.H.; Chen, X.P.; Fan, J.P. Curcumin as therapeutics for the treatment of head and neck squamous cell carcinoma by activating SIRT1. Sci. Rep. 2015, 5, 13429. [CrossRef] [PubMed] 
108. Dorai, T.; Diouri, J.; O'Shea, O.; Doty, S.B. Curcumin Inhibits Prostate Cancer Bone Metastasis by up-Regulating Bone Morphogenic Protein-7 in vivo. J. Cancer Ther. 2014, 5, 369-386. [CrossRef] [PubMed]

109. Bimonte, S.; Barbieri, A.; Leongito, M.; Piccirillo, M.; Giudice, A.; Pivonello, C.; de Angelis, C.; Granata, V.; Palaia, R.; Izzo, F. Curcumin AntiCancer Studies in Pancreatic Cancer. Nutrients 2016, 8, 433. [CrossRef] [PubMed]

110. Kanai, M. Therapeutic applications of curcumin for patients with pancreatic cancer. World J. Gastroenterol. 2014, 20, 9384-9391. [PubMed]

111. Lin, Y.G.; Kunnumakkara, A.B.; Nair, A.; Merritt, W.M.; Han, L.Y.; Armaiz-Pena, G.N.; Kamat, A.A.; Spannuth, W.A.; Gershenson, D.M.; Lutgendorf, S.K.; et al. Curcumin inhibits tumor growth and angiogenesis in ovarian carcinoma by targeting the nuclear factor-kB pathway. Clin. Cancer Res. 2007, 13, 3423-3430. [CrossRef] [PubMed]

112. Bill, M.A.; Nicholas, C.; Mace, T.A.; Etter, J.P.; Li, C.; Schwartz, E.B.; Fuchs, J.R.; Young, G.S.; Lin, L.; Lin, J.; et al. Structurally modified curcumin analogs inhibit STAT3 phosphorylation and promote apoptosis of human renal cell carcinoma and melanoma cell lines. PLoS ONE 2012, 7, e40724. [CrossRef] [PubMed]

113. Seo, B.R.; Min, K.J.; Cho, I.J.; Kim, S.C.; Kwon, T.K. Curcumin significantly enhances dual PI3K/Akt and mTOR inhibitor NVP-BEZ235-induced apoptosis in human renal carcinoma Caki cells through down-regulation of p53-dependent Bcl-2 expression and inhibition of Mcl-1 protein stability. PLoS ONE 2014, 9, e95588. [CrossRef] [PubMed]

114. Woo, J.H.; Kim, Y.H.; Choi, Y.J.; Kim, D.G.; Lee, K.S.; Bae, J.H.; Min, D.S.; Chang, J.S.; Jeong, Y.J.; Lee, Y.H.; et al. Molecular mechanisms of curcumin-induced cytotoxicity: Induction of apoptosis through generation of reactive oxygen species, down-regulation of Bcl-XL and IAP, the release of cytochrome $\mathrm{c}$ and inhibition of Akt. Carcinogenesis 2003, 24, 1199-1208. [CrossRef] [PubMed]

115. Xu, S.; Yang, Z.; Fan, Y.; Guan, B.; Jia, J.; Gao, Y.; Wang, K.; Wu, K.; Wang, X.; Zheng, P.; et al. Curcumin enhances temsirolimus-induced apoptosis in human renal carcinoma cells through upregulation of YAP/p53. Oncol. Lett. 2016, 12, 4999-5006. [CrossRef] [PubMed]

116. Zhang, H.; Xu, W.; Li, B.; Zhang, K.; Wu, Y.; Xu, H.; Wang, J.; Zhang, J.; Fan, R.; Wei, J. Curcumin Promotes Cell Cycle Arrest and Inhibits Survival of Human Renal Cancer Cells by Negative Modulation of the PI3K/AKT Signaling Pathway. Cell Biochem. Biophys. 2015, 73, 681-686. [CrossRef] [PubMed]

117. Karim, S.; Al-Maghrabi, J.A.; Farsi, H.M.; Al-Sayyad, A.J.; Schulten, H.J.; Buhmeida, A.; Mirza, Z.; Al-Boogmi, A.A.; Ashgan, F.T.; Shabaad, M.M.; et al. Cyclin D1 as a therapeutic target of renal cell carcinoma-A combined transcriptomics, tissue microarray and molecular docking study from the Kingdom of Saudi Arabia. BMC Cancer 2016, 16 (Suppl. S2), 741. [CrossRef] [PubMed]

118. Pei, C.S.; Wu, H.Y.; Fan, F.T.; Wu, Y.; Shen, C.S.; Pan, L.Q. Influence of curcumin on HOTAIR-mediated migration of human renal cell carcinoma cells. Asian Pac. J. Cancer Prev. 2014, 15, 4239-4243. [CrossRef] [PubMed]

119. Bhaumik, S.; Jyothi, M.D.; Khar, A. Differential modulation of nitric oxide production by curcumin in host macrophages and NK cells. FEBS Lett. 2000, 483, 78-82. [CrossRef]

120. Choudhuri, T.; Pal, S.; Agwarwal, M.L.; Das, T.; Sa, G. Curcumin induces apoptosis in human breast cancer cells through p53-dependent BAX induction. FEBS Lett. 2002, 512, 334-340. [CrossRef]

121. Wu, S.H.; Hang, L.W.; Yang, J.S.; Chen, H.Y.; Lin, H.Y.; Chiang, J.H.; Lu, C.C.; Yang, J.L.; Lai, T.Y.; Ko, Y.C.; et al. Curcumin induces apoptosis in human non-small cell lung cancer NCI-H460 cells through ER stress and caspase cascade- and mitochondria-dependent pathways. Anticancer Res. 2010, 30, 2125-2133. [PubMed]

122. Kim, D.G.; Kwon, T.K.; Park, J.W.; Lee, K.S. Curcumin Induces Apoptosis and Inhibits Metalloproteinase Activity in Renal Cancer Cell Line. Korean J. Urol. 2002, 43, 423-430.

123. Elfiky, A.A.; Aziz, S.A.; Conrad, P.J.; Siddiqui, S.; Hackl, W.; Maira, M.; Robert, C.L.; Kluger, H.M. Characterization and targeting of phosphatidylinositol-3 kinase (PI3K) and mammalian target of rapamycin (mTOR) in renal cell cancer. J. Transl. Med. 2011, 9, 133. [CrossRef] [PubMed]

124. Bai, N.; Zhang, C.; Liang, N.; Zhang, Z.; Chang, A.; Yin, J.; Li, Z.; Luo, N.; Tan, X.; Luo, N.; et al. Yes-associated protein (YAP) increases chemosensitivity of hepatocellular carcinoma cells by modulation of p53. Cancer Biol. Ther. 2013, 14, 511-520. [CrossRef] [PubMed]

125. Schutte, U.; Bisht, S.; Heukamp, L.C.; Kebschull, M.; Florin, A.; Haarmann, J.; Hoffmann, P.; Bendas, G.; Buettner, R.; Brossart, P.; et al. Hippo signaling mediates proliferation, invasiveness, and metastatic potential of clear cell renal cell carcinoma. Transl. Oncol. 2014, 7, 309-321. [CrossRef] [PubMed] 
126. Jung, E.M.; Lim, J.H.; Lee, T.J.; Park, J.W.; Choi, K.S.; Kwon, T.K. Curcumin sensitizes tumor necrosis factor-related apoptosis-inducing ligand (TRAIL)-induced apoptosis through reactive oxygen species-mediated upregulation of death receptor 5 (DR5). Carcinogenesis 2005, 26, 1905-1913. [CrossRef] [PubMed]

127. Caruso, F.; Rossi, M.; Benson, A.; Opazo, C.; Freedman, D.; Monti, E.; Gariboldi, M.B.; Shaulky, J.; Marchetti, F.; Pettinari, R.; et al. Ruthenium-arene complexes of curcumin: X-ray and density functional theory structure, synthesis, and spectroscopic characterization, in vitro antitumor activity, and DNA docking studies of (p-cymene)Ru(curcuminato)chloro. J. Med. Chem. 2012, 55, 1072-1081. [CrossRef] [PubMed]

128. Dandawate, P.R.; Vyas, A.; Ahmad, A.; Banerjee, S.; Deshpande, J.; Swamy, K.V.; Jamadar, A.; Dumhe-Klaire, A.C.; Padhye, S.; Sarkar, F.H. Inclusion complex of novel curcumin analogue CDF and $\beta$-cyclodextrin (1:2) and its enhanced in vivo anticancer activity against pancreatic cancer. Pharm. Res. 2012, 29, 1775-1786. [CrossRef] [PubMed]

129. Lee, J.W.; Hong, H.M.; Kwon, D.D.; Pae, H.; Jeong, H.J. Dimethoxycurcumin, a Structural Analogue of Curcumin, Induces Apoptosis in Human Renal Carcinoma Caki Cells Through the Production of Reactive Oxygen Species, the Release of Cytochrome c, and the Activation of Caspase-3. Korean J. Urol. 2010, 51, 810-878. [CrossRef] [PubMed]

130. Prasad, S.; Tyagi, A.K.; Aggarwal, B.B. Recent developments in delivery, bioavailability, absorption and metabolism of curcumin: The golden pigment from golden spice. Cancer Res. Treat. 2014, 46, 2-18. [CrossRef] [PubMed]

131. Setthacheewakul, S.; Mahattanadul, S.; Phadoongsombut, N.; Pichayakorn, W.; Wiwattanapatapee, R. Development and evaluation of self-microemulsifying liquid and pellet formulations of curcumin, and absorption studies in rats. Eur. J. Pharm. Biopharm. 2010, 76, 475-485. [CrossRef] [PubMed]

132. Tomren, M.A.; Masson, M.; Loftsson, T.; Tonnesen, H.H. Studies on curcumin and curcuminoids XXXI. Symmetric and asymmetric curcuminoids: Stability, activity and complexation with cyclodextrin. Int. J. Pharm. 2007, 338, 27-34. [CrossRef] [PubMed]

133. Shi, T.; Liou, L.S.; Sadhukhan, P.; Duan, Z.H.; Novick, A.C.; Hissong, J.G.; Almasan, A.; DiDonato, J.A. Effects of resveratrol on gene expression in renal cell carcinoma. Cancer Biol. Ther. 2004, 3, 882-888. [CrossRef] [PubMed]

134. Kim, C.; Baek, S.H.; Um, J.Y.; Shim, B.S.; Ahn, K.S. Resveratrol attenuates constitutive STAT3 and STAT5 activation through induction of PTPepsilon and SHP-2 tyrosine phosphatases and potentiates sorafenib-induced apoptosis in renal cell carcinoma. BMC Nephrol. 2016, 17, 19. [CrossRef] [PubMed]

135. Yang, R.; Zhang, H.; Zhu, L. Inhibitory effect of resveratrol on the expression of the VEGF gene and proliferation in renal cancer cells. Mol. Med. Rep. 2011, 4, 981-983. [PubMed]

136. Li, S.; Priceman, S.J.; Xin, H.; Zhang, W.; Deng, J.; Liu, Y.; Huang, J.; Zhu, W.; Chen, M.; Hu, W.; et al. Icaritin inhibits JAK/STAT3 signaling and growth of renal cell carcinoma. PLoS ONE 2013, 8, e81657. [CrossRef] [PubMed]

137. Yang, Y.; Paik, J.H.; Cho, D.; Cho, J.A.; Kim, C.W. Resveratrol induces the suppression of tumor-derived $\mathrm{CD} 4{ }^{+} \mathrm{CD} 25^{+}$regulatory T cells. Int. Immunopharmacol. 2008, 8, 542-547. [CrossRef] [PubMed]

138. Chen, L.; Yang, S.; Liao, W.; Xiong, Y. Modification of Antitumor Immunity and Tumor Microenvironment by Resveratrol in Mouse Renal Tumor Model. Cell Biochem. Biophys. 2015, 72, 617-625. [CrossRef] [PubMed]

139. Hahm, E.R.; Sakao, K.; Singh, S.V. Honokiol activates reactive oxygen species-mediated cytoprotective autophagy in human prostate cancer cells. Prostate 2014, 74, 1209-1221. [CrossRef] [PubMed]

140. Lee, Y.J.; Lee, Y.M.; Lee, C.K.; Jung, J.K.; Han, S.B.; Hong, J.T. Therapeutic applications of compounds in the Magnolia family. Pharmacol. Ther. 2011, 130, 157-176. [CrossRef] [PubMed]

141. Luo, L.X.; Li, Y.; Liu, Z.Q.; Fan, X.X.; Duan, F.G.; Li, R.Z.; Yao, X.J.; Leung, E.L.; Liu, L. Honokiol Induces Apoptosis, G1 Arrest, and Autophagy in KRAS Mutant Lung Cancer Cells. Front. Pharmacol. 2017, 8, 199. [CrossRef] [PubMed]

142. Singh, T.; Gupta, N.A.; Xu, S.; Prasad, R.; Velu, S.E.; Katiyar, S.K. Honokiol inhibits the growth of head and neck squamous cell carcinoma by targeting epidermal growth factor receptor. Oncotarget 2015, 6, 21268-21282. [CrossRef] [PubMed]

143. Tian, W.; Deng, Y.; Li, L.; He, H.; Sun, J.; Xu, D. Honokiol synergizes chemotherapy drugs in multidrug resistant breast cancer cells via enhanced apoptosis and additional programmed necrotic death. Int. J. Oncol. 2013, 42, 721-732. [CrossRef] [PubMed] 
144. Wang, X.; Duan, X.; Yang, G.; Zhang, X.; Deng, L.; Zheng, H.; Deng, C.; Wen, J.; Wang, N.; Peng, C.; et al. Honokiol crosses BBB and BCSFB, and inhibits brain tumor growth in rat 9L intracerebral gliosarcoma model and human U251 xenograft glioma model. PLoS ONE 2011, 6, e18490. [CrossRef] [PubMed]

145. Cheng, S.; Castillo, V.; Welty, M.; Eliaz, I.; Sliva, D. Honokiol inhibits migration of renal cell carcinoma through activation of RhoA/ROCK/MLC signaling pathway. Int. J. Oncol. 2016, 49, 1525-1530. [CrossRef] [PubMed]

146. Li, W.; Wang, Q.; Su, Q.; Ma, D.; An, C.; Ma, L.; Liang, H. Honokiol suppresses renal cancer cells' metastasis via dual-blocking epithelial-mesenchymal transition and cancer stem cell properties through modulating miR-141/ZEB2 signaling. Mol. Cells 2014, 37, 383-388. [CrossRef] [PubMed]

147. Gu, Y.; Zhu, C.F.; Iwamoto, H.; Chen, J.S. Genistein inhibits invasive potential of human hepatocellular carcinoma by altering cell cycle, apoptosis, and angiogenesis. World J. Gastroenterol. 2005, 11, 6512-6517. [CrossRef] [PubMed]

148. Liu, Y.L.; Zhang, G.Q.; Yang, Y.; Zhang, C.Y.; Fu, R.X.; Yang, Y.M. Genistein induces G2/M arrest in gastric cancer cells by increasing the tumor suppressor PTEN expression. Nutr. Cancer 2013, 65, 1034-1041. [CrossRef] [PubMed]

149. Mai, Z.; Blackburn, G.L.; Zhou, J.R. Genistein sensitizes inhibitory effect of tamoxifen on the growth of estrogen receptor-positive and HER2-overexpressing human breast cancer cells. Mol. Carcinog. 2007, 46, 534-542. [CrossRef] [PubMed]

150. Wu, T.C.; Yang, Y.C.; Huang, P.R.; Wen, Y.D.; Yeh, S.L. Genistein enhances the effect of trichostatin A on inhibition of A549 cell growth by increasing expression of TNF receptor-1. Toxicol. Appl. Pharmacol. 2012, 262, 247-254. [CrossRef] [PubMed]

151. Sasamura, H.; Takahashi, A.; Miyao, N.; Yanase, M.; Masumori, N.; Kitamura, H.; Itoh, N.; Tsukamoto, T. Inhibitory effect on expression of angiogenic factors by antiangiogenic agents in renal cell carcinoma. Br. J. Cancer 2002, 86, 768-773. [CrossRef] [PubMed]

152. Sasamura, H.; Takahashi, A.; Yuan, J.; Kitamura, H.; Masumori, N.; Miyao, N.; Itoh, N.; Tsukamoto, T. Antiproliferative and antiangiogenic activities of genistein in human renal cell carcinoma. Urology 2004, 64, 389-393. [CrossRef] [PubMed]

153. Majid, S.; Dar, A.A.; Ahmad, A.E.; Hirata, H.; Kawakami, K.; Shahryari, V.; Saini, S.; Tanaka, Y.; Dahiya, A.V.; Khatri, G.; et al. BTG3 tumor suppressor gene promoter demethylation, histone modification and cell cycle arrest by genistein in renal cancer. Carcinogenesis 2009, 30, 662-670. [CrossRef] [PubMed]

154. Hirata, H.; Ueno, K.; Nakajima, K.; Tabatabai, Z.L.; Hinoda, Y.; Ishii, N.; Dahiya, R. Genistein downregulates onco-miR-1260b and inhibits Wnt-signalling in renal cancer cells. Br. J. Cancer 2013, 108, 2070-2078. [CrossRef] [PubMed]

155. Negrette-Guzman, M.; Huerta-Yepez, S.; Vega, M.I.; Leon-Contreras, J.C.; Hernandez-Pando, R.; Medina-Campos, O.N.; Rodriguez, E.; Tapia, E.; Pedraza-Chaverri, J. Sulforaphane induces differential modulation of mitochondrial biogenesis and dynamics in normal cells and tumor cells. Food chem. Toxicol. 2017, 100, 90-102. [CrossRef] [PubMed]

156. Juengel, E.; Euler, S.; Maxeiner, S.; Rutz, J.; Justin, S.; Roos, F.; Khoder, W.; Nelson, K.; Bechstein, W.O.; Blaheta, R.A. Sulforaphane as an adjunctive to everolimus counteracts everolimus resistance in renal cancer cell lines. Phytomedicine 2017, 27, 1-7. [CrossRef] [PubMed]

157. Juengel, E.; Maxeiner, S.; Rutz, J.; Justin, S.; Roos, F.; Khoder, W.; Tsaur, I.; Nelson, K.; Bechstein, W.O.; Haferkamp, A.; et al. Sulforaphane inhibits proliferation and invasive activity of everolimus-resistant kidney cancer cells in vitro. Oncotarget 2016, 7, 85208-85219. [CrossRef] [PubMed]

158. Lee, H.M.; Moon, A. Amygdalin Regulates Apoptosis and Adhesion in Hs578T Triple-Negative Breast Cancer Cells. Biomol. Ther. 2016, 24, 62-66. [CrossRef] [PubMed]

159. Chen, Y.; Ma, J.; Wang, F.; Hu, J.; Cui, A.; Wei, C.; Yang, Q.; Li, F. Amygdalin induces apoptosis in human cervical cancer cell line HeLa cells. Immunopharmacol. Immunotoxicol. 2013, 35, 43-51. [CrossRef] [PubMed]

160. Makarevic, J.; Tsaur, I.; Juengel, E.; Borgmann, H.; Nelson, K.; Thomas, C.; Bartsch, G.; Haferkamp, A.; Blaheta, R.A. Amygdalin delays cell cycle progression and blocks growth of prostate cancer cells in vitro. Life Sci. 2016, 147, 137-142. [CrossRef] [PubMed]

161. Qian, L.; Xie, B.; Wang, Y.; Qian, J. Amygdalin-mediated inhibition of non-small cell lung cancer cell invasion in vitro. Int. J. Clin. Exp. Pathol. 2015, 8, 5363-5370. [PubMed] 
162. Juengel, E.; Afschar, M.; Makarevic, J.; Rutz, J.; Tsaur, I.; Mani, J.; Nelson, K.; Haferkamp, A.; Blaheta, R.A. Amygdalin blocks the in vitro adhesion and invasion of renal cell carcinoma cells by an integrin-dependent mechanism. Int. J. Mol. Med. 2016, 37, 843-850. [CrossRef] [PubMed]

163. Juengel, E.; Thomas, A.; Rutz, J.; Makarevic, J.; Tsaur, I.; Nelson, K.; Haferkamp, A.; Blaheta, R.A. Amygdalin inhibits the growth of renal cell carcinoma cells in vitro. Int. J. Mol. Med. 2016, 37, 526-532. [CrossRef] [PubMed]

164. Asaduzzaman Khan, M.; Tania, M.; Fu, S.; Fu, J. Thymoquinone, as an anticancer molecule: From basic research to clinical investigation. Oncotarget 2017, 8, 51907-51919. [CrossRef] [PubMed]

165. Park, E.J.; Chauhan, A.K.; Min, K.J.; Park, D.C.; Kwon, T.K. Thymoquinone induces apoptosis through downregulation of c-FLIP and Bcl-2 in renal carcinoma Caki cells. Oncol. Rep. 2016, 36, 2261-2267. [CrossRef] [PubMed]

166. Min, K.J.; Um, H.J.; Kim, J.I.; Kwon, T.K. The coffee diterpene kahweol enhances sensitivity to sorafenib in human renal carcinoma Caki cells through down-regulation of Mcl-1 and c-FLIP expression. Oncotarget 2017, 8, 83195-83206. [CrossRef] [PubMed]

167. Wang, T.; Jiang, Y.; Chu, L.; Wu, T.; You, J. Alpinumisoflavone suppresses tumour growth and metastasis of clear-cell renal cell carcinoma. Am. J. Cancer Res. 2017, 7, 999-1015. [PubMed]

168. Lin, Y.H.; Lee, C.C.; Chan, W.L.; Chang, W.H.; Wu, Y.C.; Chang, J.G. 16-Hydroxycleroda-3,13-dien-15,16-olide deregulates PI3K and Aurora B activities that involve in cancer cell apoptosis. Toxicology 2011, 285, 72-80. [CrossRef] [PubMed]

169. Liu, C.; Lee, W.C.; Huang, B.M.; Chia, Y.C.; Chen, Y.C.; Chen, Y.C. 16-Hydroxycleroda-3, 13-dien-15, 16-olide inhibits the proliferation and induces mitochondrial-dependent apoptosis through Akt, mTOR, and MEK-ERK pathways in human renal carcinoma cells. Phytomedicine 2017, 36, 95-107. [CrossRef] [PubMed]

170. Kim, C.; Lee, J.H.; Baek, S.H.; Ko, J.H.; Nam, D.; Ahn, K.S. Korean Red Ginseng Extract Enhances the Anticancer Effects of Sorafenib through Abrogation of CREB and c-Jun Activation in Renal Cell Carcinoma. Phytother. Res. 2017, 31, 1078-1089. [CrossRef] [PubMed]

(C) 2017 by the authors. Licensee MDPI, Basel, Switzerland. This article is an open access article distributed under the terms and conditions of the Creative Commons Attribution (CC BY) license (http:/ / creativecommons.org/licenses/by/4.0/). 